\title{
Development and Validation of an Instrument to Measure Attitudes towards the Use of Computer in Learning Mathematics
}

\author{
Osman Kasimu*, Ibrahim Nantomah \\ Department of Mathematics and ICT, Gambaga College of Education, Gambaga, Ghana \\ *Corresponding author: ossyola6@gmail.com
}

Received November 11, 2018; Revised December 22, 2018; Accepted January 24, 2019

\begin{abstract}
The aim of the study was to develop and validate an instrument suitable to measure attitudes towards the use of computer in learning mathematics (ATCLM). A total of 214 (132 = males: $82=$ females) teacher trainees participated in the study. Factor Analysis (FA) was performed on 47 items relating to the use of computer in learning mathematics using Principal Component Analysis with Varimax (orthogonal) rotation. With Eigen values greater than 1, FA retained 13 factors with the first accounting for $15.56 \%$ of the variability and a total of $62.39 \%$ of the variance for the entire set of variables. To examine the strength of relationship among the items, the Kaiser Meyer Olkin (KMO) and Bartlett's test were used. The KMO measure of sampling adequacy was 0.78 whiles the Bartlett's test of sphericity was significant with $\mathrm{x}^{2}=3510.253(\mathrm{p}<0.0001)$. A factor loading cut-off point of 0.40 was used as the inclusion criterion for factor interpretation. Based on these, seven factors namely: Confidence in Mathematics (CM), Confidence with Computer (CC), Mathematics Anxiety (MA), Computer Anxiety (CA), Value of using Computer for Learning Mathematics (VCLM), Interest in using Computer for Learning Mathematics (ICLM), and Anxiety in using Computer for Learning Mathematics (ACLM). Cronbach's alpha values for the 7 scales ranged from .735 to .880 .
\end{abstract}

Keywords: anxiety, attitudes, confidence, computer, development, instrument, mathematics

Cite This Article: Osman Kasimu, and Ibrahim Nantomah, "Development and Validation of an Instrument to Measure Attitudes towards the Use of Computer in Learning Mathematics." American Journal of Educational Research, vol. 7, no. 1 (2019): 104-108. doi: 10.12691/education-7-1-16.

\section{Introduction}

Information and Communication Technology (ICT) have become one of the fundamental building blocks of modern society. Many countries, including Ghana now regard the mastering of the basic skills and concepts of ICT as an important part of our educational system. With the introduction of ICT into the school curriculum, students are now expected to use ICT effectively within their lessons, regardless of the subject they are learning [1]. ICT plays a critical role in the educational systems [2]. To this end, various new models of education are evolving in response to the new opportunities that are becoming available by integrating ICT into the teaching and learning environment. The effective integration depends to a large extent on teacher's familiarity and ability in the information technology learning environment. Teachers' roles in the integration process are to create an effective, efficient atmosphere and a multimedia environment with the help of technologies. These environments are important for teacher-student interaction and communication [3].

Mathematics teachers need to know exactly how ICT is used as a teaching and learning tool, for their own purposes and to help students to use them. It has therefore become necessary to monitor how teacher trainees perceive ICT and how it can be used in the learning of mathematics in the classroom. This study is therefore aimed at developing and validating an instrument suitable to measure students' attitudes towards the use of computer in learning Mathematics.

\section{Literature Review}

Researches on the development of instrument to measure attitudes towards mathematics and computer have been done by many in the field of mathematics education. Table 1 outlines researchers and the instruments developed.

From Table 1, it is evident that little research has been conducted in terms of developing instruments for attitudes towards the use of computer in learning mathematics as in the case of $[5,6,9]$. The rest are either measuring attitudes towards mathematics or computer as in the case of $[4,8,9,13,14]$. Hence the development of this instrument will be a useful tool in determining students' attitude towards using computer in learning mathematics. 
Table 1. Previous Works by Other Researchers

\begin{tabular}{|c|c|c|c|}
\hline $\mathbf{S} / \mathbf{N}$ & Validated Instruments & Author(s)/Year & Computer/Mathematics Related Scales \\
\hline 11 & Students' Attitudes Towards Mathematics & {$[4]$} & Anxiety, Confidence, Enjoyment, and Benefit/Value \\
\hline 22 & $\begin{array}{l}\text { Developing an attitude scale towards using } \\
\text { instructional technologies for pre-service } \\
\text { teachers }\end{array}$ & {$[5]$} & $\begin{array}{l}\text { Believe regarding usage of instructional technology in lesson, } \\
\text {-Appreciation to usage of instructional technology in lesson, } \\
\text {-Unappreciated using instructional technology, } \\
\text {-Disinclination to make use of instructional technology, Believe in } \\
\text { usefulness of instructional technology }\end{array}$ \\
\hline 33 & $\begin{array}{l}\text { Validation of a Questionnaire to Measure } \\
\text { Mathematics Confidence, Computer } \\
\text { Confidence, and Attitudes to the Use of } \\
\text { Technology for Learning Mathematics }\end{array}$ & {$[6]$} & $\begin{array}{l}\text {-General confidence in mathematics, } \\
\text {-General confidence with computer use, } \\
\text {-General confidence using computers to learn mathematics }\end{array}$ \\
\hline 44 & $\begin{array}{l}\text { Construct Validity for the Teachers' Attitudes } \\
\text { Toward Computers Questionnaire }\end{array}$ & {$[7]$} & $\begin{array}{l}\text { - Interest, } \\
\text { - Comfort, } \\
\text { - Accommodation, } \\
\text { - Concern, } \\
\text { - Utility, } \\
\text { - Perception, } \\
\text { - Absorption, } \\
\text { - Significance }\end{array}$ \\
\hline 55 & $\begin{array}{l}\text { Development and Validation of an Inventory } \\
\text { for Measuring Student Attitudes Toward } \\
\text { Calculus }\end{array}$ & {$[8]$} & $\begin{array}{l}\text {-Self-confidence, } \\
\text { - Value, } \\
\text { - Enjoyment, } \\
\text { - Motivation }\end{array}$ \\
\hline 66 & $\begin{array}{l}\text { A scale for monitoring students_attitudes to } \\
\text { learning mathematics with technology }\end{array}$ & {$[9]$} & $\begin{array}{l}\text {-Mathematics confidence, } \\
\text {-Confidence with technology, } \\
\text {-Attitude towards use of technology for learning mathematics, } \\
\text {-Affective and behavioral engagement }\end{array}$ \\
\hline 77 & $\begin{array}{l}\text { The Computer Usefulness Attitude Scale } \\
\text { (CAS) }\end{array}$ & {$[10]$} & $\begin{array}{l}\text { - Confidence, } \\
\text { - Liking, } \\
\text { - Anxiety, } \\
\text { - Usefulness }\end{array}$ \\
\hline 88 & $\begin{array}{l}\text { An Instrument to Measure Mathematics } \\
\text { Attitudes }\end{array}$ & {$[11]$} & $\begin{array}{l}\text {-Self-confidence, } \\
\text { - Value, } \\
\text { - Enjoyment, } \\
\text { - Motivation }\end{array}$ \\
\hline 99 & $\begin{array}{l}\text { The Computer Attitudes Scale for Secondary } \\
\text { Students (CASS) }\end{array}$ & {$[12]$} & $\begin{array}{l}\text { - Avoidance of, } \\
\text {-Negative attitudes toward, } \\
\text { - Caution with computers, } \\
\text { - Cognitive, affective, and behavioral attitudes }\end{array}$ \\
\hline 110 & The Computer Attitude Questionnaire (CAQ) & {$[13,14]$} & $\begin{array}{l}\text { - Computer importance, } \\
\text { - Computer enjoyment, } \\
\text { - Computer anxiety, } \\
\text { - Computer seclusion }\end{array}$ \\
\hline 111 & The Computer Survey Scale & {$[15]$} & - Efficacy and anxiety \\
\hline
\end{tabular}

\section{Methodology}

\subsection{Participants}

The participants for the study were level 200 teacher trainees from three colleges of education in the northern region of Ghana. A total of 214 (132= males: $82=$ females $)$ teacher trainees responded to the questionnaire. Of this number, 124, 21, 56 and 13 were offering General programme, Mathematics, Science, and French respectively. The researchers personally administered the questionnaire to the participants in their various colleges.

\subsection{Instrument Development Process}

The instrument (ATCLM) was designed as a tool for measuring attitudes towards the use of computer in learning mathematics. The ATCLM consisted of 47 items, some of which were generated by the authors with some selected and modified from $[1,9,16]$. Each item was presented as a statement with 7 statements each for the Confidence in Mathematics (CM), Confidence with Computer (CC), Mathematics Anxiety (MA), and Computer Anxiety (CA) scales. The other scales such as the Value of using computer for learning mathematics (VCLM), Interest in using computer for learning mathematics (ICLM) and Anxiety in using computer for learning mathematics (ACLM) had 5, 8 and 6 items respectively. A mixture of both positive and negative worded items were used to reduce response bias. A five - point Likert scale was used to rate each item in terms of, $1=$ Strongly Disagree (SD), $2=$ Disagree (D), $3=$ Undecided (U), $4=$ Agree (A) and 5 $=$ Strongly Agree (SA). In responding to each of the items under a particular scale, respondents were asked to indicate the extent to which they agree or disagree to the items on the five-point Likert scale. A higher score indicated a more positive attitude towards using computer in learning mathematics. The negatively worded items 
were reverse coded before the computation of the Cronbach's alpha coefficient.

\subsection{Factor Analysis Process}

Exploratory Factor Analysis (EFA) was performed on 47 items relating to the use of computer in learning mathematics using Principal Component Analysis with Varimax (orthogonal) rotation. Using Eigen values greater than 1, the EFA retained 13 factors with the first accounting for $15.56 \%$ of the variability and a total of $62.39 \%$ of the variance for the entire set of variables. Initially, to examine the strength of relationship among the items, the Kaiser Meyer Olkin (KMO) and Bartlett's test were used. The KMO measure of sampling adequacy was 0.78 , above the commonly recommended value of 0.5 by [17]. The Bartlett's test of sphericity was also significant with $\mathrm{x}^{2}=3510.253(\mathrm{p}<0.0001)$. The communalities of the 47 items ranged between 0.56 and 0.72 , confirming that each item shared some common variance with other items. The Test gave the indication that factor analysis was suitable for the data. As recommended by $[18,19]$, a factor loading cut-off point of 0.40 was used as the inclusion criterion for factor interpretation. Based on these, the seven scales were further retained, namely:

i. Confidence in Mathematics (CM)

ii. Value of using computer for learning mathematics (VCLM)

iii. Confidence with Computer (CC)

iv. Interest in using computer for learning mathematics (ICLM)

v. Mathematics Anxiety (MA)

vi. Anxiety in using computer for learning mathematics (ACLM)

vii. Computer Anxiety (CA).

Table 2. Factor Loadings for the Items

\begin{tabular}{|c|c|c|c|c|c|c|c|c|}
\hline \multirow[b]{3}{*}{ Item Code } & \multicolumn{8}{|c|}{ Rotated Component Matrix ${ }^{\mathrm{a}}$} \\
\hline & \multicolumn{8}{|l|}{ Component } \\
\hline & Items & CM & $\mathbf{C C}$ & MA & CA & VCLM & ICLM & ACLM \\
\hline CM2 & Mathematics is not difficult for me & .870 & & & & & & \\
\hline CM4 & I study mathematics more willingly than any other subject & .782 & & & & & & \\
\hline CM3 & I am confident that I understand concepts in mathematics & .663 & & & & & & \\
\hline CM1 & I have a lot of self-confidence when it comes to mathematics & .640 & & & & & & \\
\hline CM5 & I have avoided mathematics because it is difficult for me & .541 & & & & & & \\
\hline CM6 & When I have difficulties with mathematics, I know I can handle them & .508 & & & & & & \\
\hline $\mathrm{CC} 10$ & I am more confident in using computer to do my school work & & .794 & & & & & \\
\hline $\mathrm{CC} 13$ & I am always very excited about using computers. & & .772 & & & & & \\
\hline CC8 & I can master any computer program needed for school & & .680 & & & & & \\
\hline CC9 & $\begin{array}{l}\text { I have less trouble learning how to use a computer than I do learning } \\
\text { other subjects. }\end{array}$ & & .568 & & & & & \\
\hline $\mathrm{CC} 11$ & Using a computer is very frustrating & & .544 & & & & & \\
\hline MA19 & Working mathematics is very frustrating & & & .723 & & & & \\
\hline MA15 & I feel nervous when working mathematics. & & & .688 & & & & \\
\hline MA16 & I do not have a mathematical mind. & & & 649 & & & & \\
\hline MA21 & I wish that mathematics was not an important subject & & & .595 & & & & \\
\hline MA20 & I am always excited to take mathematics test. & & & .535 & & & & \\
\hline MA17 & I worry about making mistakes when solving problems in mathematics & & & .521 & & & & \\
\hline CA27 & I feel tense whenever working on a computer & & & & .677 & & & \\
\hline CA24 & I worry about making mistakes on the computer & & & & .650 & & & \\
\hline CA25 & $\begin{array}{l}\text { I have avoided computers because they are unfamiliar and somewhat } \\
\text { intimidating to me }\end{array}$ & & & & .577 & & & \\
\hline CA22 & Working with a computer makes me nervous & & & & .545 & & & \\
\hline CA23 & $\begin{array}{l}\text { I wish that I could be as calm as others appear to be when they are using } \\
\text { computers }\end{array}$ & & & & .498 & & & \\
\hline VCLM32 & Computers can be useful instructional aids in almost all subject areas. & & & & & .749 & & \\
\hline VCLM33 & Computers help to incorporate new teaching and learning methods & & & & & .654 & & \\
\hline VCLM31 & Computing power makes it easier to explore mathematical ideas. & & & & & .630 & & \\
\hline VCLM29 & Having computer skills helps one get better mathematics related jobs. & & & & & .576 & & \\
\hline ICLM40 & I learn swiftly mathematics topics when computer is use. & & & & & & .720 & \\
\hline ICLM39 & $\begin{array}{l}\text { I regularly use computer in mathematics to help me solve mathematics } \\
\text { problems. }\end{array}$ & & & & & & .672 & \\
\hline ICLM41 & I can learn many concepts in mathematics when a computer is use & & & & & & .660 & \\
\hline ICLM34 & I like using computer for learning mathematics. & & & & & & .590 & \\
\hline ICLM38 & I feel motivated learning mathematics when computer is use. & & & & & & .538 & \\
\hline ACLM43 & $\begin{array}{l}\text { Working mathematics with a computer makes me feel tense and } \\
\text { uncomfortable }\end{array}$ & & & & & & & .685 \\
\hline ACLM47 & Working with a computer makes me feel tense and uncomfortable & & & & & & & .670 \\
\hline ACLM44 & $\begin{array}{l}\text { I know computers are important but I don't feel I need to use them to } \\
\text { learn mathematics. }\end{array}$ & & & & & & & .624 \\
\hline ACLM46 & $\begin{array}{l}\text { I get a sinking feeling when I think of trying to use computer to learn } \\
\text { mathematics. }\end{array}$ & & & & & & & .588 \\
\hline
\end{tabular}

NOTE: The item codes in the first column of Table 2 represent the item numbers and the corresponding scales they are measuring. For example, CM2 is item number 2 which is measuring Confidence in Mathematics; CC13 is the $13^{\text {th }}$ item which is measuring Confidence in Computer, etc. 
From Table 2, it is seen that out of the initial 47 items, 35 are loaded onto the seven scales based on the strength of the loads. 6 items (CM2, CM4, CM3, CM1, CM5 and CM6) are loaded onto the Confidence in Mathematics scale. This scale measures the confidence level of teacher trainees towards mathematics. The second scale, Confidence with Computer had 5 items (CC10, CC13, $\mathrm{CC} 8, \mathrm{CC} 9$ and $\mathrm{CC} 11)$ loading onto it. It measures teacher trainees' confidence level in working with computer. The third scale, Mathematics Anxiety had 6 items (MA19, MA15, MA16, MA21, MA20 and MA17). These items measure the anxiety level of teacher trainees. The Computer Anxiety, Value of using computer for learning mathematics, Interest in using computer for learning mathematics, and Anxiety in using computer for learning mathematics scales each had 5 (CA27, CA24, CA25, CA22 and CA23), 4 (VCLM32, VCLM33, VCLM31 and VCLM29), 5 (ICLM40, ICLM39, ICLM41, ICLM34 and ICLM38), and 4 (ACLM43, ACLM47, ACLM44 and ACLM46) items loads respectively.

\subsection{Reliability Analysis of the Instrument}

According to [20], the term reliability generally refers to the consistency of a measure. Reliability analysis on the seven scales was performed and their corresponding Chronbach's coefficient alpha recorded. Chronbach's coefficient alpha estimates the consistency of items included in a questionnaire. Values range from 0 to 1 , with higher values $(>.7)$ indicating greater reliability [19].

Table 3. Reliability Analysis

\begin{tabular}{|l|c|c|}
\hline Scales & $\begin{array}{c}\text { Number of } \\
\text { Items }\end{array}$ & $\begin{array}{c}\text { Chronbach's } \\
\text { coefficient alpha }\end{array}$ \\
\hline Confidence in Mathematics (CM) & 6 & .854 \\
\hline Confidence with Computer (CC) & 5 & .762 \\
\hline Mathematics Anxiety (MA) & 6 & .891 \\
\hline Computer Anxiety (CA) & 5 & .786 \\
\hline $\begin{array}{l}\text { Value of using Computer for } \\
\text { Learning Mathematics (VCLM) }\end{array}$ & 4 & .735 \\
\hline $\begin{array}{l}\text { Interest in Uuing Computer for } \\
\text { Learning Mathematics (ICLM) }\end{array}$ & 5 & .880 \\
\hline $\begin{array}{l}\text { Anxiety in using Computer for } \\
\text { Learning Mathematics (ACLM) }\end{array}$ & 4 & .751 \\
\hline Total & 35 & .933 \\
\hline
\end{tabular}

From Table 3, the Cronbach's alpha for the seven scales ranged from .735 to .880 with a total of 0.933 , which indicates a high level of internal consistency for our scales.

\section{Summary and Conclusions}

The aim of the study was to develop and validate an instrument suitable to measure attitudes towards the use of computer in learning mathematics (ATCLM). Review of literature reveal that most instruments developed are mostly centered on attitudes towards mathematics or computer with very little work on the use of computers in learning mathematics. A total of $214(132=$ males: $82=$ females $)$ teacher trainees participated in the study. Factor Analysis (FA) performed on an initial 47 items relating to the use of computer in learning mathematics retained 13 factors with the first accounting for $15.56 \%$ of the variability and a total of $62.39 \%$ of the variance for the entire set of variables. A factor loading cut-off point of 0.40 was used as the inclusion criterion for factor interpretation and the initial 47 items were reduced to 35 . These 35 items loaded on to 7 factors (scales) namely: Confidence in Mathematics (CM), Confidence with Computer (CC), Mathematics Anxiety (MA), Computer Anxiety (CA), Value of using Computer for Learning Mathematics (VCLM), Interest in using Computer for Learning Mathematics (ICLM), and Anxiety in using Computer for Learning Mathematics (ACLM). Cronbach's alpha values for the 7 scales ranged from .735 to .880 with a total of 0.933 , which indicates a high level of internal consistency for the scales.

Based on the above results, the instrument (ATCLM) was developed (See appendix) and will be a good tool to be used by researchers in determining the attitudes of students towards the use of computers in learning mathematics.

\section{References}

[1] Smalley, N., Graff, M. and Saunders, D. A revised computer attitude scale for secondary students. Educational and Child Psychology, 18(3), 47-57. 2001.

[2] Cavas, B., Cavas, P., Karaoglan, B., and Kisla, T. A study on science teachers' attitudes toward information and communication technologies in education. The Turkish Online Journal of Educational Technology, 8(2), 1303-6521. 2009.

[3] Metin, M., Yilmaz, G. K., Coskun, K. and Birisci, S. Developing an attitude scale towards using instructional technologies for preservice teachers. The Turkish Online Journal of Educational Technology, 11(1), 36-45. 2012.

[4] Kasimu O., and Imoro M. Studentse attitudes towards mathematics: the case of private and public Junior High Schools in the East Mamprusi District, Ghana. IOSR Journal of Research \& Method in Education (IOSR-JRME), 7(5), 38-43. 2017.

[5] Metin, M., Yilmaz, G. K., Coskun, K. and Birisci, S. Developing an attitude scale towards using instructional technologies for preservice teachers. The Turkish Online Journal of Educational Technology, 11(1), 36-45. 2012.

[6] Fogarty, G. J., Cretchley, P., Harman, C., Ellerton, N. and Konki, N. Validation of a questionnaire to measure mathematics confidence, computer confidence, and attitudes to the use of technology for learning mathematics. Mathematics Education Research Journal, 13(2): 154-160. 2001.

[7] Rhonda, W., Christensen, G. and Knezek, A. Construct validity for the teachers' attitudes toward computers questionnaire. Journal of Computing in Teacher Education, 25(4), 143-155. 2009.

[8] Yun-Chen, H. and Shu-Hui, L. Development and validation of an inventory for measuring student attitudes toward calculus. Measurement and evaluation in counseling and development, 48(2), 109-123. 2015.

[9] Pierce, R., Stacey, K. and Barkatsas, A.. A scale for monitoring students attitudes to learning mathematics with technology. Computers \& Education, 48(7), 285-300. 2006.

[10] Gressard, C. P., and Loyd, B. H. Validation studies of a new computer attitude scale. Association for Educational Data Systems Journal,18(4), 295-301. 1986.

[11] Tapia, M., and Marsh II, G. An instrument to measure mathematics attitudes. Academic Exchange Quarterly, 8(2), 1-8. 2004.

[12] Jones, T., and Clarke, V. A. A computer attitude scale for secondary students. Computers in Education, 22(4), 315-318. 1994.

[13] Knezek, G., and Miyashita, K. Handbook for the young children's computer inventory. Denton, TX: Texas Center for Educational Technology. 1993. (Supplement for CAQ available online at http://tcet.unt.edu/pubs/attcomp.htm). 
[14] Knezek, G., and Christensen, R. Validating the Computer Attitude Questionnaire (CAQ). New Orleans: Southwest Educational Research Association Annual Conference. 1996. (ERIC Document Reproduction Service, No. ED260696).

[15] Stevens, D. J. Educators' perceptions of computers in education: 1979 and 1982. Association for Educational Data Systems Journal, 145(1), 1-15. 1982

[16] Fennema, E. and Sherman, J. A. Fennema-Sherman Mathematics Attitudes Scales: Instruments designed to measure attitudes toward the learning of mathematics by males and females. Catalog of
Selected Documents in Psychology, 6(1), 31-40. 1976.

[17] Kaiser, H.,F. And Index of Factorial Simplicity. Psychometrika, 39(1), 31-36. 1974.

[18] Stevens, J. P. Applied multivariate statistics for the social sciences (4th ed.). Hillsdale, NJ: Erlbaum. 2002.

[19] Field, A. P. Discovering statistics using SPSS. (3rd ed.). London: Sage. 2009.

[20] Cohen, J.W. Statistical power analyses for the behavioral sciences (2nd ed). Hillsdale, NJ: Lawrence Erlbaum associates. 1988.

(C) The Author(s) 2019. This article is an open access article distributed under the terms and conditions of the Creative Commons Attribution (CC BY) license (http://creativecommons.org/licenses/by/4.0/). 